Article

\title{
Bacterial Toxicity Testing: Modification and Evaluation of the Luminescent Bacteria Test and the Respiration Inhibition Test
}

\author{
Uwe Strotmann ${ }^{1, * \mathbb{D}}$, Daniel Pastor Flores ${ }^{1,2}$, Odorico Konrad ${ }^{3}$ and Cornelia Gendig ${ }^{1}$ \\ 1 Department of Chemistry, Westfälische Hochschule, University of Applied Sciences, \\ August-Schmidt-Ring 10, 45665 Recklinghausen, Germany; dpflores@kbibiopharma.com (D.P.F.); \\ cornelia.gendig@w-hs.de (C.G.) \\ 2 KBI Biopharma BVBA, Technologielaan 8, 3001 Leuven, Belgium \\ 3 Laboratory of Bioreactors, Univates University, Rua Avelino Tallini, 171, 95900 Lajeado/RS, Brazil; \\ okonrad@univates.br \\ * Correspondence: uwe.strotmann@w-hs.de; Tel.: +49-(0)2361-915-579
}

Received: 30 September 2020; Accepted: 22 October 2020; Published: 25 October 2020

\begin{abstract}
The activated sludge respiration inhibition test and the luminescent bacteria test with Vibrio fischeri are important bacterial test systems for evaluation of the toxicity of chemical compounds. These test systems were further optimized to result in better handling, reliability and sensitivity. Concerning the Vibrio fischeri test, media components such as yeast extract and bivalent cation concentrations like $\mathrm{Ca}^{2+}$ and $\mathrm{Mg}^{2+}$ were optimized. The cultivation, storage conditions and reactivation process of the stored bacteria were also improved, which enabled simpler handling and led to good reproducibility. Additionally, the respiration inhibition test with a prolonged incubation time was further analyzed using different chlorinated phenols as reference compounds. It could be stated that a longer incubation period significantly improved the sensitivity of the test system.
\end{abstract}

Keywords: bacterial toxicity; chlorinated phenols; $\mathrm{Cr}(\mathrm{VI})$ and $\mathrm{Zn}(\mathrm{II})$ cations; luminescent bacteria; respiration inhibition; activated sludge; long-term toxicity

\section{Introduction}

The assessment of toxicity in water by simple, reliable and rapid test systems has been a crucial issue for environmental safety and protection. Due to their high sensitivity for toxicants, various bioassays based on bacteria, protozoa and algae are particularly suitable for rapid analyses. In practice, these bioassays are based on complex metabolic processes such as respiration, nitrification [1-8] and bioluminescence [3,9-11]. In addition, enzymatic processes such as the estimation of dehydrogenase activity [12,13] and the growth of bacteria in a pure or in mixed culture [14-17] have been used. As eukaryotic organisms, pure cultures of algae have been serving as reliable test organisms for bioassays $[18,19]$. All these tests aim at the determination of the toxicity data of pure chemicals and chemical mixtures in an aqueous environment. The luminescent bacteria test using Vibrio fischeri, which is now designated as Aliivibrio fischeri, is a widely accepted bacterial toxicity test and has been normalized by the ISO (International Organisation for Standardization) [11]. It is predominantly used to determine the toxicity of wastewaters, aqueous eluates and leachates from waste deposits $[20,21]$. Furthermore, Vibrio fischeri can also be used for the determination of toxicity of gases such as benzene, trichloroethylene and acetone when the luminous bacteria are entrapped in a complex membrane [22].

Additionally, the luminescent bacteria test proved to be a reliable test for the determination of toxicity for pure chemicals, chemical mixtures and wastewaters [3,20,23-28]. For this purpose, often test kits using conserved, freeze-dried Vibrio fischeri cells are used, but it is also possible to use freshly 
prepared cells or cells which have been frozen [11]. On the other hand, certain problems have often arisen when using frozen cells. When reactivating these cells, there can be variations in viability which can cause unreliable results in a toxicity test.

For this reason, attempts were made to further improve the cultivation of Vibrio fischeri, as well as the freezing and reactivation process, in order to create an improved ISO 11348 test method. In detail, the cultivation medium and the reactivation medium should be optimized. Additionally, the duration of the conservation period for the frozen bacteria should be enhanced. Moreover, the reliability of the overall improved procedure should be evaluated with reference compounds like 3.5- dichlorophenol, as well as zinc (II) and chromium (VI) ions. A new modified method would enable more laboratories to use the Vibrio fischeri test as an important screening test without being dependent on commercially available test kits.

Besides the luminescence of Vibrio fischeri, the respiration activity of activated sludge bacteria can be used for setting up a reliable test system for measuring bacterial toxicity. The respiration inhibition test with activated sludge is another widely used and reliable test system for the evaluation of toxicity, and it has been internationally standardized [7]. This test is generally performed at incubation times of 30 and $180 \mathrm{~min}$ in order to determine acute toxicity. However, there is also a prolonged test version with an incubation time of $27 \mathrm{~h}$, intended to give a hint to the subchronic or chronic inhibitory effects of toxicants. This prolonged test system also proved to show a higher sensitivity for 3.5-dichlorophenol [1].

In this study, the prolonged test system should be examined in further detail to evaluate the toxicity of further different reference compounds, such as dichlorophenols and also 3.4-dichloroaniline, to give more insight into the usability of this test system modification. The principal aim of this investigation was to establish the prolonged test system as an equivalent method to the established short-term methods to achieve a higher versatility of testing. This modification could also be integrated in the appropriate ISO and OECD (Organization for Economic Cooperation and Development) protocols to further update standardized test methods.

In general, ISO and OECD test methods play a crucial role when results from toxicity tests are taken to make hazard or risk assessments for certain chemicals or chemical mixtures. Therefore, a regular update of these test methods and research in this field are of great importance.

\section{Materials and Methods}

\subsection{Luminescent Bacteria Tests}

An overall scheme highlighting the main steps for the preparation of Vibrio fischeri for the luminescent bacteria test is given in Figure 1.

\subsubsection{ISO 11348-1 Medium}

The composition of the ISO 11348-1 medium is described in Table 1. To prepare $1 \mathrm{~L}$ of the medium, the components were dissolved in $500 \mathrm{~mL}$ demineralized water, and the $\mathrm{pH}$ was adjusted to $\mathrm{pH}$ $7.0 \pm 0.2$ using $\mathrm{HCl}(0.1-1 \mathrm{M})$ or $\mathrm{NaOH}(0.1-1 \mathrm{M})$. Then, the volume was filled up to $1000 \mathrm{~mL}$ with demineralized water, and the medium was sterilized $\left(121^{\circ} \mathrm{C}, 20 \mathrm{~min}\right)$. For the agar plates, $12 \mathrm{~g} \mathrm{~L}^{-1}$ of agar were added. For the optimization processes, $\mathrm{Ca}^{2+}$ ions were added as $\mathrm{CaCl}_{2} \cdot \mathrm{H}_{2} \mathrm{O}$ and additional $\mathrm{Mg}^{2+}$ ions as $\mathrm{MgSO}_{4} \cdot 7 \mathrm{H}_{2} \mathrm{O}$. 


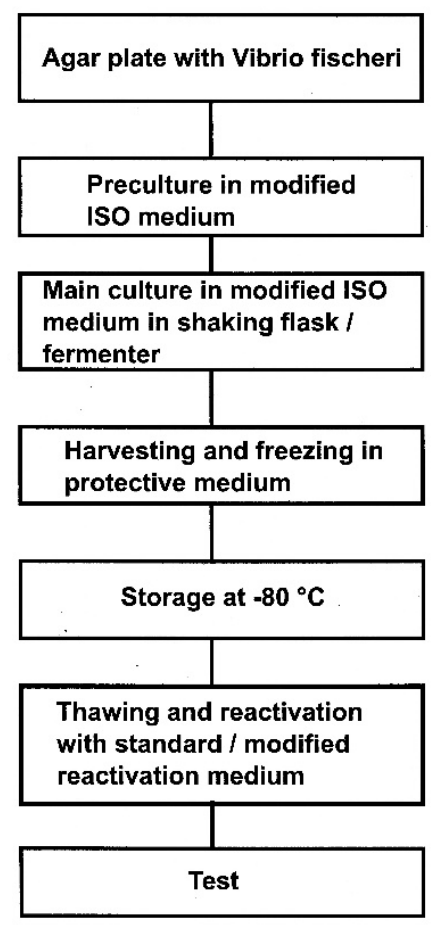

Figure 1. Schematic view of the procedure of preparing luminescent bacteria for a test.

Table 1. Composition of the original and modified growth medium. Differences to the original medium are indicated in bold.

\begin{tabular}{|c|c|c|}
\hline Compound & $\begin{array}{l}\text { Conc. in } \mathrm{gL}^{-1}(\mathrm{mM}) \text { in the ISO } 11348 \\
\text { Part } 1 \text { Growth Medium }\end{array}$ & $\begin{array}{l}\text { Conc. in } \mathrm{gL}^{-1}(\mathrm{mM}) \text { in the } \\
\text { Modified Growth Medium }\end{array}$ \\
\hline $\mathrm{NaCl}$ & $30(513)$ & $30(513)$ \\
\hline $\mathrm{Na}_{2} \mathrm{PO}_{4} \cdot \mathrm{H}_{2} \mathrm{O}$ & $6.10(38.38)$ & $6.10(38.38)$ \\
\hline $\mathrm{K}_{2} \mathrm{HPO}_{4} \cdot 3 \mathrm{H}_{2} \mathrm{O}$ & $2.75(12.05)$ & $2.75(12.05) *$ \\
\hline $\mathrm{MgSO}_{4} \cdot 7 \mathrm{H}_{2} \mathrm{O}$ & $0.204(0.83)$ & $0.204(0.83)$ \\
\hline $\mathrm{CaCl}_{2} \cdot 2 \mathrm{H}_{2} \mathrm{O}$ & $0.0(0.0)$ & $0.176(1.2)$ \\
\hline$\left(\mathrm{NH}_{4}\right)_{2} \mathrm{HPO}_{4}$ & $0.5(3.79)$ & $0.5(3.79)$ \\
\hline Glycerol $(87 \%, \mathrm{w} / \mathrm{w}) * * *$ & $3 \mathrm{~mL}(34.9) * *$ & $3 \mathrm{~mL}(34.9) * *$ \\
\hline Peptone (from casein) & 5.0 & 5.0 \\
\hline Yeast extract & 0.5 & 5.0 \\
\hline
\end{tabular}

\subsubsection{Precultures, Main Cultures and Fermenter Cultivation}

Precultures and main cultures of Vibrio fischeri NRRL B-11177 (Aliivibrio fischeri DSM 7151, Leibniz-Institut DSMZ, Braunschweig, Germany) were prepared in an ISO 11348-1 medium. Precultures were inoculated with bacteria from an agar plate culture and incubated in $50 \mathrm{~mL}$ shaking flasks (medium volume of $10 \mathrm{~mL}$ ) at room temperature for $24 \mathrm{~h}$, with a shaking speed of $120 \mathrm{rpm}$. Main cultures were cultivated in $500 \mathrm{~mL}$ shaking flasks containing $100 \mathrm{~mL}$ of the medium. The cultivation was also performed on a rotatory shaker (Braun Melsungen, Germany) at a shaking speed of $120 \mathrm{rpm}$ for $24 \mathrm{~h}$ at room temperature. The inoculation occurred with $1 \mathrm{~mL}$ of a grown preculture.

Fermenter cultivations were performed in an Infors Minifors fermenter (Infors AG, Bottmingen, Switzerland) with an operating volume of $1.5 \mathrm{~L}$. As a medium, the ISO 11348-1 medium was used. The fermenter was inoculated with $15 \mathrm{~mL}$ of a grown preculture. The stirring rate during the cultivation process was $150 \mathrm{rpm}$, the oxygen supply was as high as possible and the temperature was adjusted to $20^{\circ} \mathrm{C}$. The $\mathrm{pH}$ was kept at $\mathrm{pH} 7.0 \pm 0.2$ by adding $0.1 \mathrm{M} \mathrm{HCl}$ or $0.1 \mathrm{M} \mathrm{NaOH}$. Fermenter cultivations were performed up to $72 \mathrm{~h}$ and then stopped, as high cell titers could cause an oxygen depletion. 
Afterward, the cells were harvested by centrifugation $\left(6000 \mathrm{~g}, 20 \mathrm{~min}, 4^{\circ} \mathrm{C}\right)$, and the pellet was washed twice with an ice-cold $\mathrm{NaCl}$ solution $\left(2 \%, \mathrm{w} / \mathrm{v}, 200 \mathrm{~mL} \mathrm{~L}^{-1}\right.$ of culture) and, finally, carefully resuspended under stirring and constant cooling on ice in a protective medium $\left(80 \mathrm{~mL} \mathrm{~L}^{-1}\right.$ of culture, Section 2.1.3). The turbidity of the suspension should be in the range of $2500 \pm 500 \mathrm{FAU}$. This suspension could be directly used, or it could be frozen in aliquots at $-80^{\circ} \mathrm{C}$. This procedure was also used for shaking flask cultures.

\subsubsection{Protective Medium}

The protective medium consisted of the following (per $100 \mathrm{~mL}$ ): $66 \mathrm{~g}$ D-Glucose monohydrate, $4 \mathrm{~g} \mathrm{NaCl}, 2 \mathrm{~g}$ L-Histidine and $0.5 \mathrm{~g}$ bovine serum albumin (BSA). The components were dissolved in $80 \mathrm{~mL}$ of water at a temperature of $37^{\circ} \mathrm{C}$, and the $\mathrm{pH}$ was adjusted to $\mathrm{pH} 7.0 \pm 0.2$ using $\mathrm{HCl}(0.1-1 \mathrm{M})$ or $\mathrm{NaOH}(0.1-1 \mathrm{M})$. Then, the solution was filled up to a final volume of $100 \mathrm{~mL}$. This solution served for the protection of bacterial cells from damage by the freezing process. This medium was freshly prepared prior to use.

\subsubsection{Reactivation Medium and Reactivation Process}

The medium consisted of the following (per liter): $8.0 \mathrm{~g}$ D-Glucose monohydrate, $20.0 \mathrm{~g} \mathrm{NaCl}$, $2.04 \mathrm{~g} \mathrm{MgSO}_{4} \cdot 7 \mathrm{H}_{2} \mathrm{O}, 0.30 \mathrm{~g} \mathrm{KCl}$ and $11.9 \mathrm{~g}$ HEPES (4-(2-hydroxyethyl)-1-piperazineethanesulfonic acid). The components were dissolved in $800 \mathrm{~mL}$ of water, and the $\mathrm{pH}$ was adjusted to $\mathrm{pH} 7.0 \pm 0.2$ using $\mathrm{HCl}(0.1-1 \mathrm{M})$ or $\mathrm{NaOH}(0.1-1 \mathrm{M})$. Then, the solution was filled up to $1000 \mathrm{~mL}$. This medium served for the reactivation of the luminescent bacteria after thawing them. A modified reactivation medium contained all components mentioned above, with the exception of HEPES and $\mathrm{KCl}$. As a buffer substance, $25 \mathrm{mM}$ of $\mathrm{Na}_{2} \mathrm{HPO}_{4}$ was added, and the $\mathrm{pH}$ was adjusted to $\mathrm{pH} 7.0 \pm 0.2$. Next, $100 \mu \mathrm{L}$ of the frozen bacteria were thawed in a water bath at a temperature of $20^{\circ} \mathrm{C}$ and mixed with $500 \mu \mathrm{L}$ of reactivation medium. This suspension rested for $15 \mathrm{~min}$ at a temperature of $15^{\circ} \mathrm{C}$. Then, the suspension was transferred to $20 \mathrm{~mL}$ vials, and an additional $11.5 \mathrm{~mL}$ of the reactivation medium was added. This bacteria suspension was kept at $15{ }^{\circ} \mathrm{C}$ and was ready for use.

\subsubsection{Performance of the Luminescence Bacteria Test}

For all luminescence activity tests, a temperate luminometer (LUMIStox ${ }^{\mathrm{TM}}$, Dr. Lange, Düsseldorf, Germany) was used. A precooled $2 \%(\mathrm{w} / \mathrm{v}) \mathrm{NaCl}$ solution $\left(\mathrm{T}=15^{\circ} \mathrm{C}\right)$ was used for all necessary dilution procedures. The test was performed at $15^{\circ} \mathrm{C}$.

For a test, each vial contained $500 \mu \mathrm{L}$ of a bacteria suspension. The toxicant was added at different volumes from a concentrated stock solution, and the vial was filled up with an $\mathrm{NaCl}$ solution to a final volume of $1000 \mu \mathrm{L}$.

As a control assay, the luminescence change of an assay only containing the bacteria suspension $t$ was determined during the incubation time. From these data, a correction factor $f$ was estimated according to:

$$
\mathrm{f}=\mathrm{L}_{\mathrm{t}} / \mathrm{L}_{0}
$$

where $\mathrm{L}_{0}$ is the initial luminescence and $\mathrm{L}_{t}$ is the luminescence after the time $t$.

Then, the corrected initial luminescence $\left(\mathrm{L}_{0 \mathrm{C}}\right)$ was determined with the following equation:

$$
\mathrm{L}_{0 \mathrm{C}}=\mathrm{L}_{0} * \mathrm{f}
$$

In an assay containing the toxicant, the luminescence after the required incubation time $\left(\mathrm{L}_{\mathrm{t}}\right)$ and the luminescence change $\Delta \mathrm{L}\left(\Delta \mathrm{L}=\mathrm{L}_{0 \mathrm{C}}-\mathrm{L}_{\mathrm{t}}\right)$ were determined.

Further details of the test performance have been described by ISO 11348-1 [11]. The reference compounds used were prepared as stock solutions according to the same protocol. The relative luminescence activity was given in Irel, as indicated by the manufacturer. 


\subsubsection{Calculation of Inhibition Data}

The inhibitory effect (\%I, or percentage inhibition) of a test compound in the luminescence inhibition test was calculated as:

$$
\% \mathrm{I}=\left(\Delta \mathrm{L} / \mathrm{L}_{0 \mathrm{C}}\right) * 100
$$

The effective concentrations (ECs), causing 20\%, 50\% and 80\% inhibition (EC20, EC50 and EC80), were determined according to the ISO 11348 part 1 through 3 protocols. All determinations were performed at least four times, and the appropriate $95 \%$ confidence intervals (CI) of the mean EC values were calculated with a Student's $t$-test $[29,30]$. Further statistical exploitations are described in Section 2.2.4.

\subsection{Respiration Inhibition Tests}

An overall scheme of the performance of the activated sludge respiration inhibition test is given in Figure 2.

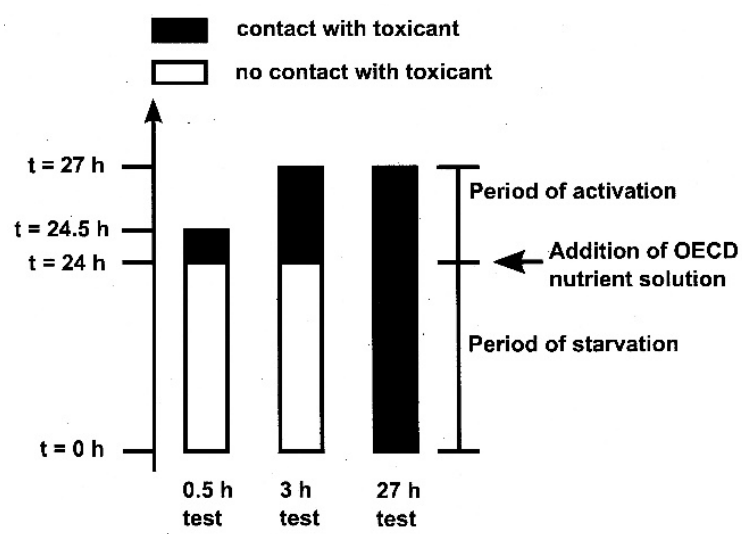

Figure 2. Schematic view of the activated sludge respiration inhibition test at different incubation times.

\subsubsection{OECD 209 Nutrient Solution}

The OECD 209 nutrient solution (synthetic feed solution) consisted of the following components (per liter): $16 \mathrm{~g}$ peptone, $11 \mathrm{~g}$ meat extract, $3 \mathrm{~g}$ urea, $0.7 \mathrm{~g} \mathrm{NaCl}, 0.2 \mathrm{~g} \mathrm{CaCl}_{2} \cdot 2 \mathrm{H}_{2} \mathrm{O}, 0.2 \mathrm{~g} \mathrm{MgSO} \cdot 7 \mathrm{H}_{2} \mathrm{O}$ and $2.8 \mathrm{~g} \mathrm{KH}_{2} \mathrm{PO}_{4}$. This medium was prepared as a 100 -fold stock solution and diluted just before use. The stock solution was stored at $-20^{\circ} \mathrm{C}$ to prevent microbial contamination and thawed prior to use.

\subsubsection{Microbial Biomass}

Activated sludge from the aeration basin of a wastewater treatment plant, treating predominantly domestic wastewater, was used as the microbial biomass for the tests and was designated in accordance with the OECD 209 [31] and ISO 8192 [7] guidelines as microbial inoculum. Before use in the test, the sludge was washed twice with tap water and starved under aeration for $24 \mathrm{~h}$. The concentration of the activated sludge was determined according to the APHA (American Public Health Association) [32] and expressed as mixed liquid suspended solids (MLSS). The $\mathrm{pH}$ of the activated sludge was adjusted to $\mathrm{pH}$ 6.8-7.2 using a hydrochloric acid solution ( $\mathrm{HCl}$ concentration: 0.1 to $1 \mathrm{M}$ ) or sodium hydroxide solution ( $\mathrm{NaOH}$ concentration: 0.1 to $1 \mathrm{M})$.

\subsubsection{Test Conditions and Performance of the Tests}

Test substances were prepared as concentrated stock solutions in demineralized water. These solutions were neutralized prior to use. In general, stock solutions were prepared by dissolving $1 \mathrm{~g}$ of the chemical in $500 \mathrm{~mL}$ of demineralized water, followed by neutralization. Then, the solutions were filled up to a final volume of $1000 \mathrm{~mL}$ with demineralized water. The contact period (incubation 
period) of the sludge with the chemical range was $30 \mathrm{~min}, 180 \mathrm{~min}$ and $27 \mathrm{~h}$ for a prolonged incubation period. The MLSS concentration in the test vessels (Karlsruher flasks) was $1.6 \mathrm{gL}^{-1}$. In the test series, the total respiration, including heterotrophic and nitrification-based respiration, was measured. The determination of the respiration rate occurred in closed vessels and was monitored with an oxygen electrode equipped with a special stirring device (WTW Trioximatic 300, Weilheim, Germany). The stirring rate was low so that an oxygen supply caused by stirring was negligible. The initial oxygen concentration ranged from 7 to $8 \mathrm{mgL}^{-1}$. Respiration activities were monitored for at least $10 \mathrm{~min}$. Long-term inhibition studies were performed according to a modified OECD 209 protocol [1].

\subsubsection{Calculation of Inhibition Data and Statistical Analysis}

The calculation of the inhibition data for the respiration inhibition test has been described by ISO 8192 [7] and OECD 209 [31]. The inhibitory effect (\%I, or percentage inhibition) of a test compound in the respiration inhibition test was calculated as:

$$
\% \mathrm{I}=1-\left(2 \mathrm{Rs} /\left(\mathrm{Rc}_{1}+\mathrm{Rc}_{2}\right)\right) \times 100
$$

where Rs is the respiration rate at a certain concentration of the test substance and $R_{1}$ and $R_{2}$ are the respiration rates of the blank and control before and after the incubation period. The effective concentrations (ECs) causing 20\%, 50\% and 80\% inhibition (EC20, EC50 and EC80) were determined. All determinations were performed at least four times, and the appropriate $95 \%$ confidence intervals $(\mathrm{CI})$ of the mean EC values were calculated with a Student's $t$-test $[29,30]$. Gamma values $(\Gamma)$ represented the ratio of percentage inhibition to percentage residual inhibition at a certain inhibitor concentration [33]. These were calculated according to the following formula:

$$
\Gamma=\% \mathrm{I} /(100-\% \mathrm{I})
$$

where $\% \mathrm{I}$ is the percentage inhibition at a certain concentration. A gamma value of 1 was equivalent to the EC50 value, whereas gamma values of 0.25 and 4 indicated EC20 and EC 80 values, respectively. A regression analysis after a logarithmic transformation (designated as a log regression, logit fit), a calculation of gamma values [33], a two-parameter and four-parameter Weibull fit [34] (designated as Weibull-2 and Weibull-4) and a probit fit were performed [1,35].

The function of the original two-parameter Weibull fit used in this examination was:

$$
\mathrm{I}=1-\mathrm{e}^{\wedge}\left(-\mathrm{e}^{\wedge}\left(\mathrm{m}_{1}+\mathrm{m}_{2}{ }^{*} \log _{10}(\text { conc. })\right)\right)
$$

where $\mathrm{m}_{1}$ and $\mathrm{m}_{2}$ are the fit parameters and I was the inhibition as an absolute value. To achieve a percentage inhibition, I had to be multiplied by 100 .

In some cases, the two-parameter Weibull fit was not able to give a saturation inhibition of $100 \%$ and a zero inhibition of $0 \%$. In order to account for these effects, the two-parameter Weibull fit was modified by introducing two more parameters, $\mathrm{m}_{3}$ and $\mathrm{m}_{4}$, resulting in a four-parameter Weibull fit.

$$
\mathrm{I}=\mathrm{m}_{3}-\mathrm{m}_{4} * \mathrm{e}^{\wedge}\left(-\mathrm{e}^{\wedge}\left(\mathrm{m}_{1}+\mathrm{m}_{2}{ }^{*} \log _{10}(\text { conc. })\right)\right)
$$

where $m_{3}$ represents the saturation value of the inhibition. The difference between $m_{3}$ and $m_{4}$ gave the baseline of the inhibition (i.e., the inhibition present at low concentration levels). Additionally, here I was the absolute inhibition and had to be multiplied by 100 to give the percentage inhibition.

The data obtained were analyzed on a MacBook Pro microcomputer, using the software packages KaleidaGraph (Synergy Software, Reading, PA, USA) and SPSS (IBM, Armonk, NY, USA). 


\section{Results}

\subsection{Modification of the Luminescent Bacteria Test}

\subsubsection{Determination of Cell Numbers}

The determination of cell numbers in different cultures was performed by the formazine method [36] and the measurement of optical density at $530 \mathrm{~nm}$ or $550 \mathrm{~nm}$. Both determination methods proved to be reliable. Correlations between the formazine turbidity and the optical densities at $530 \mathrm{~nm}$ and $550 \mathrm{~nm}$, as well as the correlation between the cell number and the optical density at $530 \mathrm{~nm}$, are shown in Figure 3.
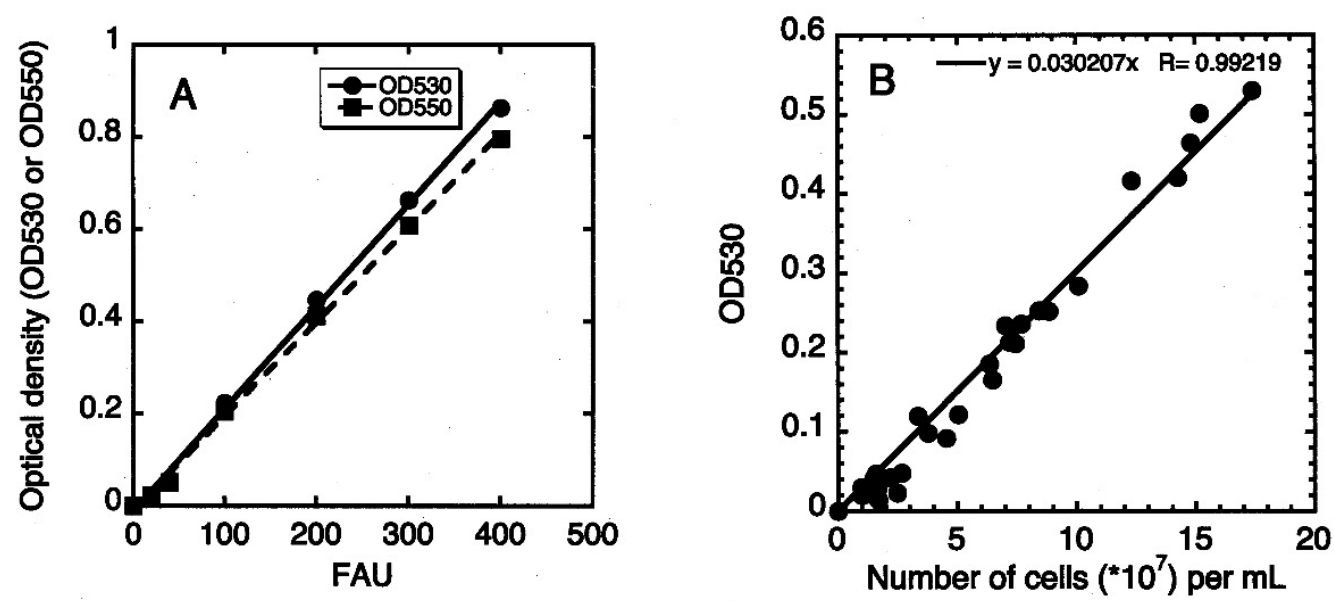

Figure 3. Determination of cell density by turbidity measurements. (A) Correlation between the formazine turbidity (FAU) and the optical densities at $530 \mathrm{~nm}$ and $550 \mathrm{~nm}$. (B) Correlation between the number of cells per volume and the optical density at $530 \mathrm{~nm}$.

\subsubsection{Yeast Extract Addition to the Growth Medium}

Yeast extract is a medium component that can positively influence the growth and metabolism of bacteria. It clearly proved to be beneficial to increase the final cell number in growth experiments, as well as an enhancement of luminescence in a concentration range of $2-5 \mathrm{~g} \mathrm{~L}^{-1}$. The data obtained are illustrated in Figure 4.

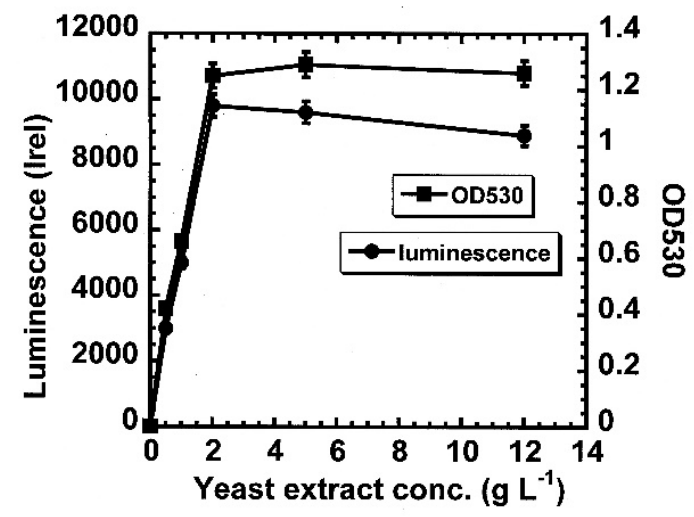

Figure 4. Luminescence and final OD530 at different yeast extract concentrations.

\subsubsection{Optimization of the Magnesium, Calcium and Potassium Concentration in the Growth Medium}

In most microbial media, sodium and potassium as monovalent cations and magnesium and calcium as bivalent cations are the most essential cations. Sodium is the overall predominant cation 
in a medium for luminescent bacteria, being present in high concentrations up to $0.513 \mathrm{M}$ as sodium chloride. For this reason, an optimization was not necessary. On the other hand, the influence of the other ions on growth and light emission was further investigated.

The optimum concentration of magnesium was above $0.4 \mathrm{mM}$ when considering light emission as a parameter. With the final cell concentration as a parameter, magnesium concentrations greater than $0.6 \mathrm{mM}$ proved to be optimal. At lower concentrations, either the light emission and the final cell density were sharply reduced (Figure 5A).
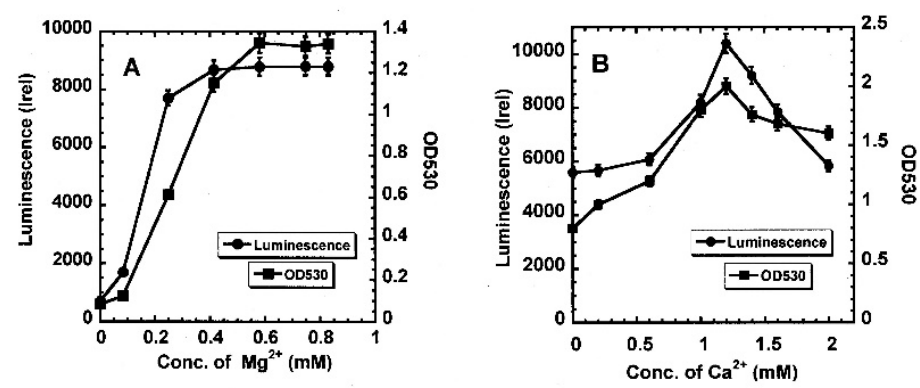

Figure 5. Optimization experiments with $\mathrm{Mg}^{2+}$ and $\mathrm{Ca}^{2+}$ ions. Influence of $(\mathbf{A}) \mathrm{Mg}^{2+}$ and (B) $\mathrm{Ca}^{2+}$ on growth and luminescence.

Calcium ions had an activating effect on growth. Concerning luminescence, a calcium concentration in the range of 1.0 to $1.4 \mathrm{mM}$ (the optimum being $1.2 \mathrm{mM}$ ) had a significant stimulating effect on Vibrio fischeri (Figure 5B).

Potassium did not prove to be as crucial a nutrient as magnesium. In an ISO 11348-1 medium without $\mathrm{K}_{2} \mathrm{HPO}_{4} \cdot 3 \mathrm{H}_{2} \mathrm{O}$ (representing a potassium free medium), Vibrio fischeri was able to grow up to a final OD530 of 1.3. In comparison, in the original ISO 11348-1 medium, a final OD530 of 1.5 was obtained. In addition, light emission was only slightly reduced when omitting potassium $(8300( \pm 110)$ Irel in a medium without potassium and $8500( \pm 120)$ Irel in a medium containing $24.1 \mathrm{mM}$ potassium). It also has to be mentioned that media without and with potassium had total phosphor-concentrations $\left(\mathrm{HPO}_{4}{ }^{2-}\right.$ and $\left.\mathrm{PO}_{4}{ }^{3-}\right)$ of $42.3 \mathrm{mM}$ and $54.3 \mathrm{mM}$, respectively, indicating that the buffering capacity of the potassium-free medium was only slightly reduced and $\mathrm{pH}$ effects could be neglected.

\subsubsection{Growth Patterns of Vibrio fischeri in Shaking Flasks and in an Aerated Fermenter}

Vibrio fischeri cells were either grown in shaking flask cultures or in an aerated fermenter in order to determine the growth rates, final cell densities and light emission. The tests were performed in an improved medium containing $5 \mathrm{gL}^{-1}$ yeast extract, $0.8 \mathrm{mM}$ magnesium, $1.2 \mathrm{mM}$ calcium and $24.1 \mathrm{mM}$ potassium (Table 1). When grown in shaking flasks, Vibrio fischeri had a lag period of $10 \mathrm{~h}$ before starting to grow. In the ISO medium, the growth rate was $2.9( \pm 0.1) \mathrm{h}^{-1}$, and the final O530 was about $1.45( \pm 0.05)$ (with a final luminescence of $11,000( \pm 50)$ Irel). In fermenter cultures with a yeast extract addition of $5 \mathrm{~g} \mathrm{~L}^{-1}$, a growth rate of $2.8( \pm 0.1) \mathrm{h}^{-1}$ and a final OD530 of $12( \pm 0.4)$ with a luminescence of $1.2 \times 10^{5}( \pm 2500)$ Irel were obtained. Due to the high cell titer, the oxygen concentration was below $0.1 \mathrm{mg} \mathrm{L}^{-1}$ when the stationary phase was reached.

\subsubsection{Influence of a Precooling Process on Cell Viability}

When freshly grown Vibrio fischeri cells are to be used in a test, the cells have to be cooled down to the test temperature of $15{ }^{\circ} \mathrm{C}$, as recommended by ISO 11348. To estimate the influence of this precooling procedure on the viability of Vibrio fischeri, cells were grown up to the stationary phase at a temperature of $25^{\circ} \mathrm{C}$ and subsequently precooled to $15{ }^{\circ} \mathrm{C}$ without shaking for time periods up to $90 \mathrm{~min}$. It could be stated that neither the cell density nor the light emission were influenced, compared to a control culture maintained at $25^{\circ} \mathrm{C}$ indicating that precooling periods up to $90 \mathrm{~min}$ had no significant influence on the viability of the cells. 
3.1.6. Storage of Luminescent Bacteria and the Influence of the Reactivation Medium

The ISO protocol recommends that freshly prepared bacteria should be stored at a temperature of $-20^{\circ} \mathrm{C}$ for later use in a toxicity test. To evaluate the influence of the storage temperature on the activity of Vibrio fischeri, samples were stored at $-20^{\circ} \mathrm{C}$ and $-80^{\circ} \mathrm{C}$ for up to seven weeks. It could be demonstrated that after a storage period of three weeks, the light emission of the bacteria stored at $-20{ }^{\circ} \mathrm{C}$ had been diminished by $87 \%$, whereas there was no decrease of light emission of a sample stored at $-80^{\circ} \mathrm{C}$. Even after a storage period of seven weeks at $-80^{\circ} \mathrm{C}$, there was no significant decrease in light emission, indicating that storage at such low temperatures was possible.

The ISO protocol recommends a reactivation medium consisting of glucose as a carbon source and a mineral salts solution containing $\mathrm{MgSO}_{4} \cdot 7 \mathrm{H}_{2} \mathrm{O}, \mathrm{KCl}$ and HEPES as a buffer substance, maintaining a $\mathrm{pH}$ of 7.0. It could be shown that HEPES could be substituted by $\mathrm{Na}_{2} \mathrm{HPO}_{4}$ without any loss of activity. Additionally, $\mathrm{KCl}$ in the reactivation medium was not necessary. The resulting EC50 values with 3.5.-dichlorophenol, obtained with the modified reactivation medium, were comparable to those with the original ISO reactivation medium. In this way, an alternative and simpler reactivation medium could be used. It also has to be noted that this modified medium is not recommended for tests with inorganic compounds, as precipitations with phosphate may occur.

\subsubsection{Sensitivity of Vibrio fischeri to 3.5-Dichlorophenol}

3.5-dichlorophenol is a widely used reference compound recommended by the ISO. The influence of the incubation time on the test performance was tested with 3.5-dichlorophenol. The test bacteria were grown in the modified medium until the stationary phase was reached after $23 \mathrm{~h}$. For the incubation with 3.5-dichlorophenol, the cultures were cooled down to $15^{\circ} \mathrm{C}$ for one hour, and different concentrations of 3.5-dichlorophenol were added. The incubation with 3.5.-dichlorophenol was performed for 5, 30 and $60 \mathrm{~min}$ at $15^{\circ} \mathrm{C}$. The EC20, EC50 and EC80 values obtained are summarized in Table 2. From these data, it is obvious that the incubation time with 3.5-dichlorophenol had no influence on the EC values obtained.

Table 2. Toxicity of 3.5-dichlorphenol at different incubation times, as determined by the modified method. The experiments served for evaluating the influence of the incubation time on EC values and as a comparison of the EC values with the standard procedure. The number of repetitions was five. $\mathrm{s}=$ standard deviation, $\mathrm{CV}=$ variation coefficient and $\mathrm{CI}=$ confidence interval.

\begin{tabular}{|c|c|c|c|c|}
\hline Parameter & Mean $\left(\mathrm{mgL}^{-1}\right)$ & $s\left(\mathrm{mg} \mathrm{L}^{-1}\right)$ & CV $(\%)$ & $95 \% \mathrm{CI}\left(\mathrm{mg} \mathrm{L}^{-1}\right)$ \\
\hline \multicolumn{5}{|c|}{5 min incubation time } \\
\hline EC20 & 1.60 & 0.41 & 25.4 & $1.10-2.10$ \\
\hline EC50 & 3.52 & 0.23 & 6.5 & $3.24-3.80$ \\
\hline EC80 & 6.64 & 0.26 & 3.9 & $6.32-6.96$ \\
\hline \multicolumn{5}{|c|}{30 min incubation time } \\
\hline EC20 & 1.42 & 0.46 & 32.0 & $0.86-1.99$ \\
\hline EC50 & 3.60 & 0.24 & 6.5 & $3.31-3.89$ \\
\hline EC80 & 6.28 & 0.30 & 4.8 & $5.90-6.66$ \\
\hline \multicolumn{5}{|c|}{60 min incubation time } \\
\hline EC20 & 1.52 & 0.36 & 23.4 & $1.08-1.96$ \\
\hline EC50 & 3.58 & 0.23 & 6.4 & $3.30-3.86$ \\
\hline EC80 & 6.80 & 0.22 & 3.3 & $6.52-7.08$ \\
\hline
\end{tabular}




\subsubsection{Estimation of Toxicity of $\mathrm{ZnSO}_{4}$ and Chromium (VI) Ions}

The toxicity of $\mathrm{ZnSO}_{4}$ (added as $\mathrm{ZnSO}_{4} \cdot 7 \mathrm{H}_{2} \mathrm{O}$ ) was also estimated at different incubation times. The results obtained are summarized in Table 3. It could be demonstrated that the EC50 values decreased with increasing incubation times. At an incubation time of $5 \mathrm{~min}$, an EC50 value of $46.56 \mathrm{mgL}^{-1}$ was obtained, whereas at incubation times of 30 and $60 \mathrm{~min}$, the EC50 values were in the range of 20.93 to $22.74 \mathrm{mgL}^{-1}$.

Table 3. Toxicity of $\mathrm{Zn}$ (II) at different incubation times, as determined by the modified method. The aim of the experiments was also the evaluation of the influence of the incubation time on the EC50 values. Furthermore, data for a comparison with the standard procedure were also provided. The number of repetitions was seven. $\mathrm{s}=$ standard deviation, $\mathrm{CV}=$ variation coefficient, $\mathrm{CI}=$ confidence interval of the mean and n.d. = not determined.

\begin{tabular}{|c|c|c|c|c|}
\hline Parameter & Mean $\left(\mathrm{mg} \mathrm{L}^{-1}\right)$ & $s\left(\mathrm{mg} \mathrm{L}^{-1}\right)$ & CV $(\%)$ & $95 \% \mathrm{CI}\left(\mathrm{mg} \mathrm{L}^{-1}\right)$ \\
\hline \multicolumn{5}{|c|}{5 min incubation time } \\
\hline EC20 & 15.54 & 2.08 & 13.35 & $13.62-17.46$ \\
\hline EC50 & 46.56 & 5.65 & 12.13 & $41.34-51.79$ \\
\hline EC80 & $>60$ & n.d. & n.d. & n.d. \\
\hline \multicolumn{5}{|c|}{30 min incubation time } \\
\hline EC20 & 5.39 & 1.20 & 22.27 & $4.28-6.50$ \\
\hline EC50 & 22.74 & 3.00 & 13.19 & $19.96-25.51$ \\
\hline EC80 & 57.09 & 10.25 & 17.95 & $47.61-66.57$ \\
\hline \multicolumn{5}{|c|}{60 min incubation time } \\
\hline EC20 & 8.66 & 1.89 & 21.79 & $6.92-10.41$ \\
\hline EC50 & 20.93 & 4.05 & 19.35 & $17.18-24.67$ \\
\hline EC80 & 46.96 & 7.88 & 16.77 & $39.68-54.25$ \\
\hline
\end{tabular}

For the estimation of the toxicity of chromium (VI) ions, $\mathrm{K}_{2} \mathrm{Cr}_{2} \mathrm{O}_{7}$ was added at different concentrations. Tests were performed with an incubation time of $30 \mathrm{~min}$, and EC20, EC50 and EC80 values were determined. The data obtained are summarized in Table 4. At an incubation time of $15 \mathrm{~min}$, chromium (VI) showed a significantly lower toxic effect than at an incubation time of $30 \mathrm{~min}$ (Figure 6). A log regression fit of the whole data set revealed EC50 values of $5.84 \mathrm{mg} \mathrm{L}^{-1}$ (30 min test) and $2.28 \mathrm{mg} \mathrm{L}^{-1}$ (30 min test). When analyzing a restricted data set (40-60\% inhibition) with a probit fit ( $\mathrm{R}>0.99)$, EC50 values of $5.14 \mathrm{mg} \mathrm{L}^{-1}$ (15 min test) and $2.59 \mathrm{mg} \mathrm{L}^{-1}$ (30 min test) were obtained.

Table 4. Toxicity of Cr (VI) at an incubation time of $30 \mathrm{~min}$, as determined by the modified method. These data served for comparative purposes with the standard procedure. The number of repetitions was seven. $\mathrm{s}=$ standard deviation, $\mathrm{CV}=$ variation coefficient and $\mathrm{CI}=$ confidence interval.

\begin{tabular}{|c|c|c|c|c|}
\hline Parameter & Mean $\left(\mathrm{mg} \mathrm{L}^{-1}\right)$ & $s\left(\mathrm{mg} \mathrm{L}^{-1}\right)$ & CV (\%) & $95 \% \mathrm{CI}\left(\mathrm{mg} \mathrm{L}^{-1}\right)$ \\
\hline EC20 & 0.75 & 0.19 & 25.03 & $0.57-0.92$ \\
\hline EC50 & 2.65 & 0.61 & 23.04 & $2.08-3.21$ \\
\hline EC80 & 4.63 & 0.55 & 11.76 & $4.13-5.14$ \\
\hline
\end{tabular}




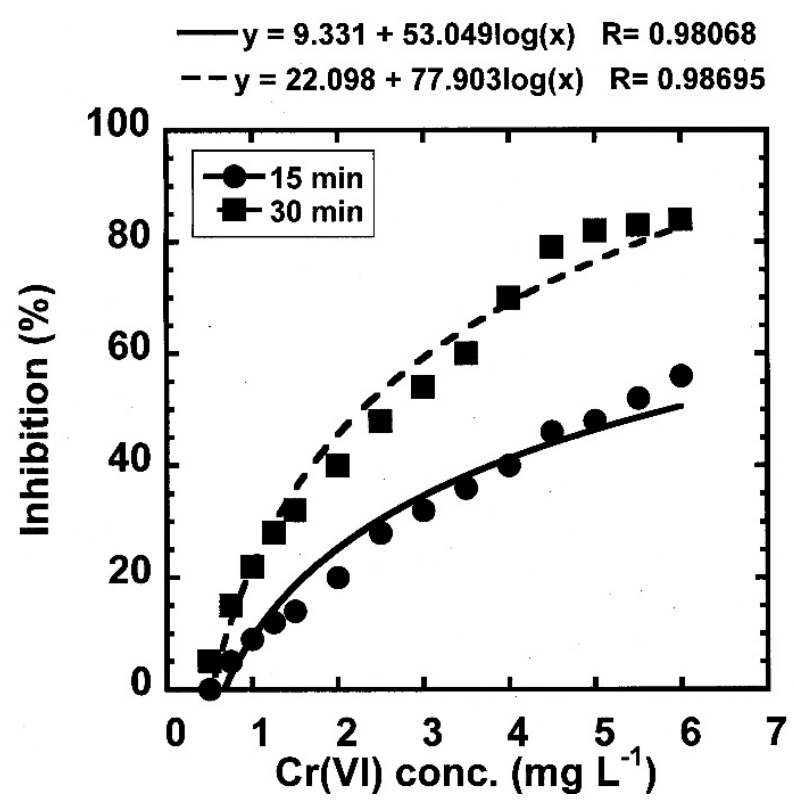

Figure 6. Determination of the toxicity of chromium (VI) ions in a $15 \mathrm{~min}$ and $30 \mathrm{~min}$ test with luminescent bacteria. The appropriate log regression curves are indicated.

\subsection{Optimization of the Activated Sludge Respiration Inhibition Test}

\subsubsection{Blank Values}

The basic respiration of activated sludge without the addition of the OECD nutrient solution (basic respiration) was in the range of 2.4-4.3 $\mathrm{mg} \mathrm{O}_{2}$ g MLLSS $^{-1} \mathrm{~h}^{-1}$. The addition of the OECD nutrient solution resulted in an increase of the specific respiration rates up to $37.8 \mathrm{mg} \mathrm{O}_{2} \mathrm{~g} \mathrm{MLSS}^{-1} \mathrm{~h}^{-1}$. As these samples did not contain any toxicant, they were designated as blank samples (controls). The mean value of these samples was $13.1 \mathrm{mg} \mathrm{O}_{2}$ g MLLSS $^{-1} \mathrm{~h}^{-1}$ (standard deviation: $7.5 \mathrm{mg} \mathrm{O}_{2}$ g MLLSS $^{-1} \mathrm{~h}^{-1}$; $95 \%$ confidence interval $9.0 \mathrm{mg} \mathrm{O}_{2}$ g MLLSS $^{-1} \mathrm{~h}^{-1}$ to $17.2 \mathrm{mg} \mathrm{O}_{2}$ g MLLSS $^{-1} \mathrm{~h}^{-1}$ ). The activating effect of the OECD nutrient solution has been described before [37]. For an incubation period of $27 \mathrm{~h}$, two parallel controls were used.

\subsubsection{Advantages of Different Statistical Exploitations}

The toxicity of 2.3-dichlorophenol in a closed incubation system was tested with municipal activated sludge. The incubation time was $27 \mathrm{~h}$, and 18 different concentrations ranging from 0.1-200 $\mathrm{mg} \mathrm{L}^{-1}$ were tested. The inhibition data obtained were interpolated with the help of four different interpolation methods (log regression, gamma fit, two-parameter Weibull fit and four-parameter Weibull fit). The effectiveness of an interpolation method is based on the regression coefficient $\mathrm{R}$ of the modeling function. The results of the interpolation are shown in Figure 7. The Weibull approximations and the log regression fit seemed to be superior to fit the whole data set $(\mathrm{R}>0.95)$. The EC50 values obtained were $6.3 \mathrm{mg} \mathrm{L}^{-1}$ (two-parameter Weibull fit), $4.9 \mathrm{mg} \mathrm{L}^{-1}$ (four-parameter Weibull fit) and $5.5 \mathrm{mg} \mathrm{L}^{-1}$ (log regression fit). The gamma fit $(\mathrm{R}=0.88)$ was in the same range and resulted in an EC50 value of $5.9 \mathrm{mg} \mathrm{L}^{-1}$. A further improvement of the gamma fit could be obtained when a restricted data set (linear part of the sigmoid curve with concentrations causing $40-60 \%$ inhibition) was analyzed. With this restricted data set, a regression coefficient $R=0.94$ could be obtained, and the resulting EC50 value was $6.1 \mathrm{mg} \mathrm{L}^{-1}$. A probit analysis of the restricted data set revealed an EC50 of $5.9 \mathrm{mg} \mathrm{L}^{-1}$ (regression coefficient $\mathrm{R}=0.997$ ). The differences between the fit models were relatively small when compared with the wide valid data range ( 5 to $30 \mathrm{mg} \mathrm{L}^{-1}$ ), indicated in the OECD 209 protocol for the comparable reference compound 3.5-dichlorophenol. In practical use, the determination of the EC50 can be performed with log regression, probit and Weibull fits. 

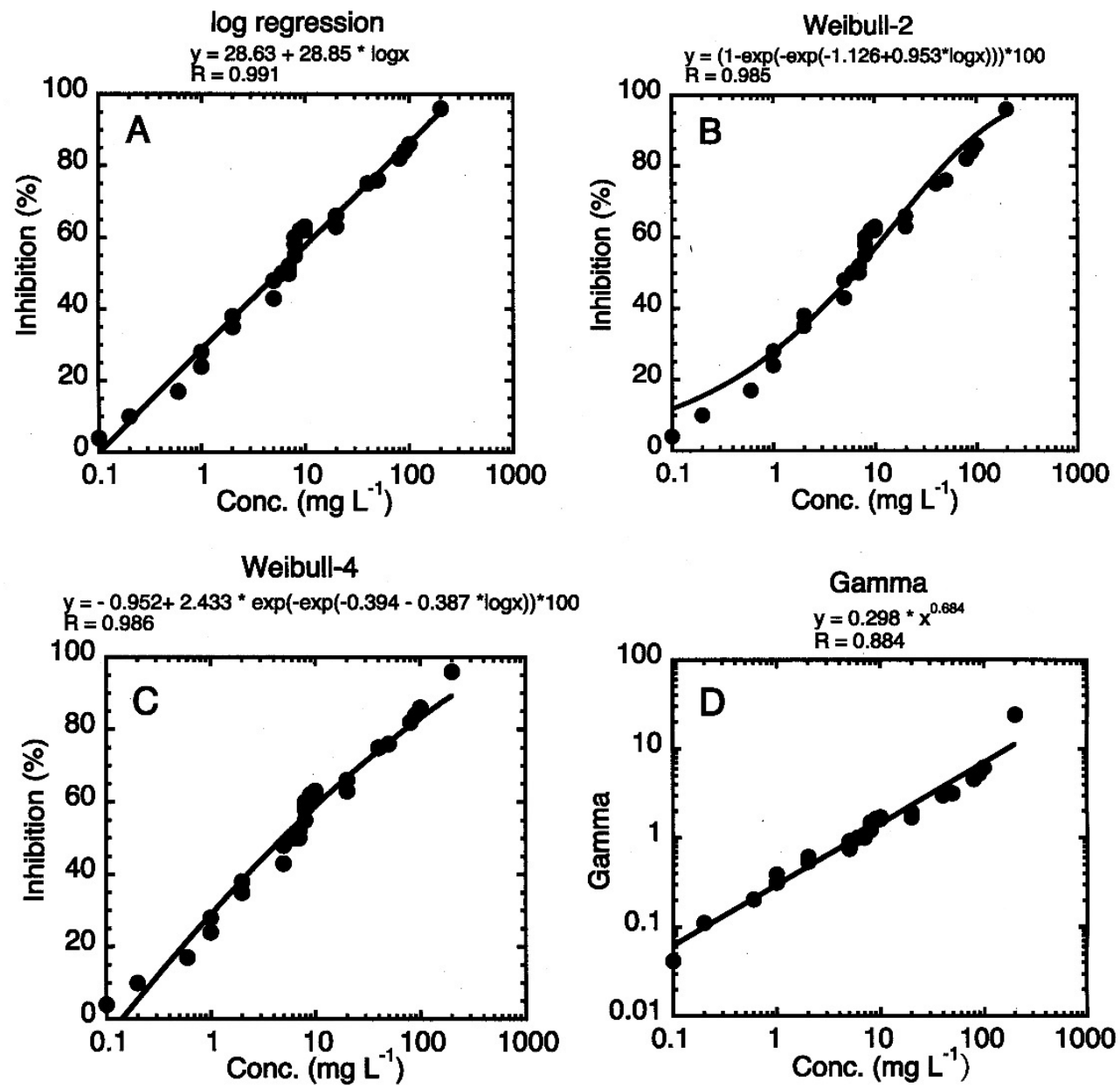

Figure 7. Toxicity data obtained with 2.3 -dichlorophenol ( $27 \mathrm{~h}$ incubation time) were analyzed by four different statistical fit procedures: (A) log-regression fit, (B) two-parameter Weibull fit, (C) four-parameter Weibull fit and (D) gamma fit.

3.2.3. Comparative Toxicity of Different Dichlorophenols and 3.4-Dichloroaniline after Long-Term Incubation

Different dichlorophenols and 3.4-dichloraniline were used to determine the toxicity of these compounds in a test system, according to the modified OECD 209 protocol with an elevated incubation time of $27 \mathrm{~h}$. The relevant EC values obtained (EC20, EC50 and EC80) are summarized in Table 5. The EC50 values of these compounds at different incubation times (30 $\mathrm{min}, 180 \mathrm{~min}$ and $27 \mathrm{~h}$ ) have been illustrated in Figure 8. It is obvious that at incubation times of 30 and $180 \mathrm{~min}$, the test substances showed significant discrepancies in the EC50 values, whereas at an incubation time of $27 \mathrm{~h}$, the EC50 values of the compounds proved to be in the same range. Furthermore, the $27 \mathrm{~h}$ test system showed a higher sensitivity for nearly all compounds tested. An exception to this observation was 3.5-dichlorophenol, where all EC50 values were in the range of 6-8 $\mathrm{mgL}^{-1}$. 
Table 5. Toxicity data for 2.3-dichlorophenol (2.3-DCP), 3.4-dichlorophenol (3.4-DCP), 3.5-dichlorophenol (3.5-DCP) and 3.4-dichloroaniline (3.4-DCA) in the long-term respiration inhibition test (27 $\mathrm{h}$ incubation time), according to the modified OECD 209 protocol. The number of single tests performed was $5 . \mathrm{s}=$ standard deviation, $\mathrm{CI}=$ confidence interval of the mean and $\mathrm{CV}=$ variation coefficient.

\begin{tabular}{|c|c|c|c|c|}
\hline \multirow[t]{2}{*}{ Parameter } & \multicolumn{4}{|c|}{ Test Compound } \\
\hline & 2.3-DCP & 3.4-DCP & 3.5-DCP & 3.4-DCA \\
\hline Mean EC20 $\left(\mathrm{mg} \mathrm{L}^{-1}\right)$ & 0.40 & 0.42 & 0.62 & 0.54 \\
\hline $95 \% \mathrm{CI}\left(\mathrm{mg} \mathrm{L}^{-1}\right)$ & $0.37-0.43$ & $0.32-0.53$ & $0.53-0.71$ & $0.48-0.60$ \\
\hline $\mathrm{s}\left(\mathrm{mg} \mathrm{L}^{-1}\right)$ & 0.02 & 0.08 & 0.07 & 0.05 \\
\hline CV $(\%)$ & 5.8 & 11.8 & 11.4 & 8.6 \\
\hline Mean EC50 $\left(\mathrm{mg} \mathrm{L}^{-1}\right)$ & 5.50 & 3.38 & 6.35 & 6.82 \\
\hline $95 \% \mathrm{CI}\left(\mathrm{mg} \mathrm{L}^{-1}\right)$ & $4.98-7.38$ & $2.11-4.65$ & $5.68-7.02$ & $5.69-7.95$ \\
\hline $\mathrm{s}\left(\mathrm{mg} \mathrm{L}^{-1}\right)$ & 0.42 & 1.02 & 0.54 & 0.91 \\
\hline CV $(\%)$ & 7.63 & 30.3 & 8.5 & 13.3 \\
\hline Mean EC80 $\left(\mathrm{mg} \mathrm{L}^{-1}\right)$ & 52.20 & 21.40 & 27.22 & 83.25 \\
\hline $95 \% \mathrm{CI}\left(\mathrm{mg} \mathrm{L}^{-1}\right)$ & $43.70-60.43$ & $12.51-30.29$ & $21.22-33.32$ & $64.72-101.78$ \\
\hline $\mathrm{s}\left(\mathrm{mg} \mathrm{L}^{-1}\right)$ & 6.63 & 7.16 & 4.87 & 11.64 \\
\hline $\mathrm{CV}(\%)$ & 12.70 & 33.5 & 17.9 & 14.0 \\
\hline
\end{tabular}

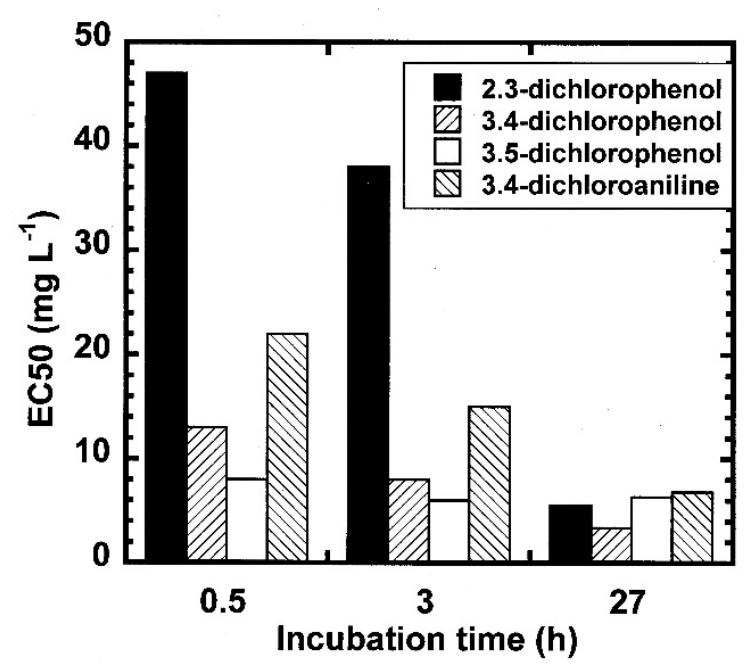

Figure 8. EC50 values for several dichlorophenols and 3.4-dichloroaniline, obtained in the respiration inhibition test at different incubation times.

\section{Discussion}

Concerning the luminescent bacteria test, Vibrio fischeri was cultivated in the modified growth medium in which high cell concentrations with high luminescence could be achieved. These cells were stored by freezing at $-80{ }^{\circ} \mathrm{C}$ for up to seven weeks and, after reactivation, the EC50 values for 3.5-dichlorophenol were determined. The EC50 values obtained were in the range of 3.5-3.6 $\mathrm{mgL}^{-1}$, even at different incubation times. These data are in good accordance with data formerly published $[3,11,38]$. The toxicity of chlorinated phenolic compounds has been studied before [3], and the EC50 data all lie in the range of $1-7 \mathrm{~mL}^{-1}$, therefore being suitable reference compounds for this test system. In contrast, the EC50 values for $\mathrm{Cr}$ (VI) cations were clearly dependent on the incubation time and were in the range of $2.65 \mathrm{mgL}^{-1}$ ( $30 \mathrm{~min}$ incubation time). Therefore, they were in good accordance to data already published [11,38]. Also, the toxicity data for $\mathrm{Zn}$ (II) cations were comparable to formerly published data $[11,38]$. On the other hand, toxicity data can also vary in a 
wide range, as indicated in the literature [38]. Influencing factors can be the composition of the growth medium, the cultivation and the storage method used. It is also possible that ionic compounds like chromium (VI) can form complexes, precipitate or be reduced [39-42]. These chemical reactions can influence the bioavailability of the compound and therefore have an effect on determined EC values. For this reason, organic compounds like chlorinated phenols, which show a high chemical stability impaired with a defined toxicity, seem to be ideal reference substances.

The new cultivation medium with an optimized yeast extract, magnesium and calcium content was very reliable for cultivation processes. The modified reactivation medium was suitable when testing organic test substances but is not recommended for testing inorganic compounds, which can precipitate with phosphate. The storage of Vibrio fischeri bacteria is now possible up to periods of seven weeks at $-80^{\circ} \mathrm{C}$, whereas ISO 11348 Part 1 strictly recommends using only fresh bacteria for regular tests and thawed bacteria only for investigative and preliminary experiments. In our opinion, a prolonged storage period does not cause any loss of activity at all, in cases where it occurs at a temperature of $-80^{\circ} \mathrm{C}$. Therefore, a modification of the ISO protocol concerning the cultivation and reactivation medium, as well as the storage period, should be taken into consideration.

Concerning the respiration inhibition test, the EC50 values obtained for 3.5-dichlorophenol in the long-term respiration inhibition test with an incubation time of $27 \mathrm{~h}$ are lower than data in other studies, with shorter incubation times of 0.5 to $3 \mathrm{~h}$. Here, an EC50 of $6.35 \mathrm{mg} \mathrm{L}^{-1}$ was measured, whereas an EC50 in the range of $10-60 \mathrm{mg} \mathrm{L}^{-1}$ was reported in former publications [43-47]. In the ISO 8192 protocol, a ring test is mentioned in which EC50 values of $9.8 \mathrm{mg} \mathrm{L}^{-1}$ and $9.3 \mathrm{mgL}^{-1}$, with incubation times of $30 \mathrm{~min}$ and $180 \mathrm{~min}$, respectively, were obtained. According to the ISO 8192 protocol, the EC50 should lie in the range of 2-25 mg L ${ }^{-1}$. In a previous study, an EC50 of $6.3 \mathrm{~m} \mathrm{~L}^{-1}$ in a long-term test system was published, whereas in 30 and 180 min tests, the EC50 values ranged from 5-9 $\mathrm{mg} \mathrm{L}^{-1}$ [1], which is in good accordance with the data presented in this study.

The suitability of the long-term incubation test was also demonstrated, especially for 2.3-dichlorophenol, where the test system showed the highest sensitivity at an elevated incubation time of $27 \mathrm{~h}$. For this reason, a modification of the OECD 209 and ISO 8192 protocols should be considered. In cases where a chemical compound has an EC50 value lower than $50 \mathrm{mg} \mathrm{L}^{-1}$ at an incubation time of 30 or $180 \mathrm{~min}$, a retest at a prolonged incubation time of $27 \mathrm{~h}$ should be recommended in order to approve or reevaluate the data.

In general, a prolongation of the incubation time of bacteria with a toxicant should result in a higher toxicity, represented by lower EC values. In this study, this assumption could be stated for 2.3-dichlorophenol, 3.4-dichlorophenol and 3.4-dichloroaniline in the respiration inhibition test and for $\mathrm{Cr}(\mathrm{VI})$ in the luminescence bacteria test. In contrast, a prolonged incubation time had no effect on the EC50 values for 3.5-dichlorphenol in the respiration inhibition test. This may be due to the mode of action of the toxicant and the kinetics of the inhibition process. To summarize, tests with a prolonged incubation time provide data with a higher safety level, which might be useful for the risk assessment of chemicals and chemical mixtures.

From the data presented, it seems to be obvious that different dichlorophenols are appropriate reference compounds for bacterial toxicity tests. In Table 6, EC50 values from different ISO and OECD normalized tests systems are summarized.

It seems to be obvious that the nitrification inhibition test is the most sensitive test system, followed by the luminescent bacteria test. The sewage bacteria growth inhibition test proved to be the most insensitive test system in several cases. The respiration inhibition test is located between the luminescent bacteria test and the sewage bacteria growth inhibition test. 
Table 6. Toxicity data for different dichlorophenols from ISO and OECD normalized bacterial toxicity tests. The data originate from this and former studies [1-3,14,15].

\begin{tabular}{|c|c|c|c|c|}
\hline Compound & $\begin{array}{c}\text { Respiration } \\
\text { Inhibition Test } \\
\text { ISO 8192, OECD } \\
209 \mathrm{EC} 50\left(\mathrm{mg} \mathrm{L}^{-1}\right)\end{array}$ & $\begin{array}{l}\text { Luminescent } \\
\text { Bacteria Test } \\
\text { ISO } 11348 \\
\text { EC50 }\left(\mathrm{mg} \mathrm{L}^{-1}\right)\end{array}$ & $\begin{array}{l}\text { Nitrification } \\
\text { Inhibition Test } \\
\text { ISO } 9509 \text { EC50 } \\
\left(\mathrm{mg} \mathrm{L}^{-1}\right)\end{array}$ & $\begin{array}{l}\text { Sewage Bacteria } \\
\text { Growth Inhibition } \\
\text { Test ISO } 15522 \\
\text { EC50 }\left(\mathrm{mg} \mathrm{L}^{-1}\right)\end{array}$ \\
\hline 2.3-dichlorophenol & $5.5-47$ & 4 & 0.09 & $40-60$ \\
\hline 3.4-dichlorophenol & $4-13$ & 1 & 0.8 & $19-26$ \\
\hline 3.5-dichlorophenol & $6-60$ & 5 & 0.5 & $5-10$ \\
\hline
\end{tabular}

Concerning the mode of an inhibitory action of dichlorophenols, the $\mathrm{pH}$ proved to have a severe influence, as shown in a dehydrogenase assay with activated sludge bacteria [13]. There in tests at $\mathrm{pH}$ values in the range of 5.5 and 6.0 lower EC50 values were obtained compared to tests performed at $\mathrm{pH}$ values of 7.0 and 7.5 , thus indicating a clear $\mathrm{pH}$ effect on toxicity.

It also has to be taken into account that toxicity data can be dependent on the source of the inoculum used $[14,15]$. A high variability of EC50 values can be explained by the choice of the inoculum used. It is obvious that sludge from a municipal wastewater treatment plant is adapted to easily biodegradable compounds, whereas sludge from an industrial wastewater treatment plant can often degrade even poorly biodegradable chemical compounds [48]. Therefore, the sludge of an industrial wastewater treatment plant is adapted to a variety of chemical compounds and can more easily tolerate potential inhibitors.

\section{Conclusions}

Bacterial toxicity tests, such as the luminescent bacteria test using Vibrio fischeri and the activated sludge respiration inhibition test, are frequently used test systems for the estimation of bacterial toxicity and have been normalized by the ISO and OECD. Nevertheless, the underlying test procedures need modifications to be further improved. It could be shown that the growth medium composition and the composition of the reactivation medium could be optimized to further facilitate test performance. Furthermore, the storage period of the frozen bacteria could be significantly prolonged. The modified method produced comparable results to the original standard procedure. To enable laboratories to cultivate Vibrio fischeri more effectively by themselves, an alternative to the use of commercially available test kits is offered. Therefore, these methodological variations should also be included in future updates to the test protocols. Concerning the respiration inhibition test, the long-term incubation method offered a higher sensitivity for certain dichlorophenols and 3.4-dichloroaniline, and it should be established as an equivalent method to the standard short-term methods in the ISO and OECD protocols. It could also be stated that certain statistical procedures, such as the log-regression, gamma, probit and Weibull fits, produce comparable results when determining the EC50 values of possible toxicants.

Author Contributions: Conceptualization, U.S. and C.G.; methodology, U.S., D.P.F. and C.G.; software, U.S. and O.K.; validation, U.S., C.G. and O.K.; formal analysis, U.S. and O.K.; investigation, C.G. and D.P.F.; resources, U.S.; data curation, U.S.; writing — original draft preparation, U.S.; writing — review and editing, U.S.; visualization, U.S. and C.G.; supervision, U.S. All authors have read and agreed to the published version of the manuscript.

Funding: This research received no external funding.

Acknowledgments: We acknowledge support by the Open Access Publication Fund of the Westfälische Hochschule, University of Applied Science

Conflicts of Interest: The authors declare no conflict of interest. 


\section{References}

1. Gendig, C.; Domogala, G.; Agnoli, F.; Pagga, U.; Strotmann, U.J. Evaluation and further development of the activated sludge respiration inhibition test. Chemosphere 2003, 52, 143-149. [CrossRef]

2. Pagga, U.; Bachner, J.; Strotmann, U. Inhibition of nitrification in laboratory tests and model wastewater treatment plants. Chemosphere 2006, 65, 1-8. [CrossRef]

3. Strotmann, U.J.; Eglsäer, H. The toxicity of substituted phenols in the nitrification inhibition test and the luminescent bacteria test. Ecotoxicol. Environ. Saf. 1995, 30, 269-273. [CrossRef]

4. Mamais, D.; Noutsopulos, C.; Stasinakis, A.S.; Kouris, N.; Andreadakis, A.D. Comparison of bioluminescence and nitrification inhibition methods for assessing toxicity to municipal activated sludge. Water Environ. Res. 2008, 80, 484-489. [CrossRef]

5. Stasinakis, A.S.; Mamais, D.; Thomaidis, N.S.; Danika, E.; Gatidou, G.; Lekkas, T. Inhibitory effect of triclosan and nonylphenol on respiration rates and ammonia removal in activated sludge systems. Ecotoxicol. Environ. Saf. 2008, 70, 199-206. [CrossRef] [PubMed]

6. Oliveira, C.A.; Araujo, C.V.M.; Nascimento, R.B.; Strotmann, U.J.; da Silva, E.M. Utilization of respirometry to assess organic matter reduction of effluents from the Camacari industrial complex (BA, Bahia). Braz. Arch. Biol. Technol. 2007, 50, 311-319. [CrossRef]

7. ISO 8192. Water Quality_Test for Inhibition of Oxygen Consumption by Activated Sludge for Carbonaceous and Ammonium Oxidation; International Organisation for Standardization: Geneva, Switzerland, 2007.

8. ISO 9509. Water Quality-Toxicity Test for Assessing the Inhibition of Nitrification of Activated Sludge Microorganisms; International Organisation for Standardization: Geneva, Switzerland, 2006.

9. Lee, S.; Sode, K.; Nakanishi KMarty, J.L.; Tamiya, E.; Karube, I. A novel microbial sensor using luminous bacteria. Biosens. Bioelectron. 1992, 7, 273-277. [CrossRef]

10. Zhou, X.; Sang, W.; Liu, S.; Zhang, Y.; Ge, H. Modeling and prediction for the acute toxicity of pesticide mixtures to the freshwater luminescent bacterium Vibrio qinghaiensis sp-Q67. J. Environ. Sci. 2010, 22, 433-440. [CrossRef]

11. ISO 11348. Water Quality-Determination of the Inhibitory Effect of Water Samples on the Light Emission of Vibrio fischeri (Luminescent Bacteria Test); Part 1: Method Using Freshly Prepared Bacteria; Part 2: Method Using Liquid-Dried Bacteria; Part 3: Method Using Freeze-Dried Bacteria; International Organisation for Standardization: Geneva, Switzerland, 2007.

12. Anderson, K.; Koopman, B.; Britton, G. Evaluation of the INT-dehydrogenase assay for heavy-metal inhibition of activated sludge. Water Res. 1988, 22, 349-353. [CrossRef]

13. Strotmann, U.; Butz, B.; Bias, W.R. The dehydrogenase assay with resazurin: Practical performance as a monitoring system and $\mathrm{pH}$-dependent toxicity of phenolic compounds. Ecotoxicol. Environ. Saf. 1993, 25, 79-89. [CrossRef]

14. Strotmann, U.J.; Eglsäer, H.; Pagga, U. Development and evaluation of a growth inhibition test with sewage bacteria for assessing bacterial toxicity of chemical compounds. Chemosphere 1994, 28, 755-766. [CrossRef]

15. Strotmann, U.J.; Pagga, U. A growth inhibition test with sewage bacteria-Results of an international ring test 1995. Chemosphere 1996, 32, 921-933. [CrossRef]

16. Alsop, G.M.; Waggy, G.T.; Conway, R.A. Bacterial growth inhibition test. J. Water Pollut. Control Fed. 1980, 52, 2452-2456.

17. ISO 15522. Water Quality-Determination of the Inhibitory Effect of Water Constituents on the Growth of Activated Sludge Microorganisms; International Organisation for Standardization: Geneva, Switzerland, 1999.

18. Kasai, F.; Hatakeyama, S. Herbicide susceptibility in 2 green algae, Chlorella vulgaris and Selenastrum capricornutum. Chemosphere 1993, 27, 899-904. [CrossRef]

19. Pardos, M.; Bennnghoff, C.; Thomas, R.J. Photosynthetic and population growth response of the test alga Selenastrum capricornutum Printz to zinc, cadmium and suspended sediment elutriates. J. Appl. Phycol. 1998, 10, 145-151. [CrossRef]

20. Oliveira, C.A.; Araujo, C.V.M.; Nascimento, R.B.; Strotmann, U.J.; da Silva, E.M. The use of Microtox ${ }^{\mathrm{TM}}$. to assess toxicity removal of industrial effluents from the industrial district of Camacari (BA, Bahia). Chemosphere 2005, 58, 1277-1281. 
21. Abbas, M.; Adil, M.; Ehtisham-ul-Haque, S.; Munir, B.; Yameen, M.; Ghaffar, A.; Abbas Shar, G.; Tahir, M.A.; Iqbal, M. Vibrio fischeri bioluminescence inhibition assay for ecotoxicity assessment: A review. Sci. Total Environ. 2018, 626, 1295-1309. [CrossRef]

22. Komori, K.; Miyajima, S.; Tsuru, T.; Fujii, T.; Mohri, S.; Ono, Y.; Sakai, Y. A rapid and simple evaluation system for gas toxicity using luminous bacteria entrapped by a polyion complex membrane. Chemosphere 2009, 77, 1106-1112. [CrossRef]

23. Arbuckle, W.B.; Alleman, J.E. Effluent toxicity using nitrifiers and Microtox ${ }^{\mathrm{TM}}$. Water Environ. Res. 1992, 64, 263-267. [CrossRef]

24. Toussaint, M.W.; Shedd, T.R.; van der Schaile, W.H.; Leather, G.R. A comparison of standard acute toxicity tests with rapid screening toxicity tests. Environ. Toxicol. Chem. 1995, 14, 907-915. [CrossRef]

25. Salizzato, M.; Bertato, V.; Pavoni, B.; Volpi Giardini, A.; Ghetti, P.F. Sensitivity limits and EC50 values of the Vibrio fischeri test for organic micropollutants in natural and spiked extracts from sediments. Environ. Toxicol. Chem. 1998, 17, 655-661. [CrossRef]

26. Rubinos, D.A.; Calvo, V.; Iglesias, L.; Barral, M.T. Acute toxicity of arsenic to Aliivibrio fischeri (Microtox ${ }^{\mathrm{TM}}$ bioassay) as influenced by potential competitive-protective agents. Environ. Sci. Pollut. Res. 2014, 21, 8631-8644. [CrossRef] [PubMed]

27. Ribo, J.M.; Kaiser, K.L.E. Photobacterium phosphoreum bioassay. I. Test procedures and Applications. Toxic. Assess. 1987, 2, 305-322. [CrossRef]

28. Kungolos, A.; Tsiridis, V.P.; Samaras, P.; Tsiropoulos, N. Toxic and interactive toxic effects of agrochemical substances and copper on Vibrio fischeri. WIT Trans. Ecol. Environ. 2006, 99. [CrossRef]

29. Townend, J. Practical Statistics for Environmental and Biological Scientists; John Wiley \& Sons Ltd.: New York, NY, USA, 2001.

30. Mann, P.S. Introductory Statistics, 4th ed.; John Wiley \& Sons Inc.: New York, NY, USA, 2001.

31. OECD. Test No. 209: Activated Sludge, Respiration Inhibition Test (Carbon and Ammonium Oxidation), OECD Guidelines for the Testing of Chemicals, Section 2; OECD Publishing: Paris, France, 2010. [CrossRef]

32. APHA. Standard Methods for Examination of Water and Wastewater, 20th ed.; American Public Health Association, Port City Press: Baltimore, MD, USA, 1998.

33. Tarkpea, M.; Hansson, M.; Samuelsson, B. Comparison of the Microtox ${ }^{\mathrm{TM}}$ test with the 96-h LC50 test for the harpactioid Nitocra spinipe. Ecotoxicol. Environ. Saf. 1986, 11, 755-766. [CrossRef]

34. Backhaus, T.; Froehner, K.; Altenburger, R.; Grimme, L.H. Toxicity testing with Vibrio fischeri: A comparison between the long term $(24 \mathrm{~h})$ and the short term (30 $\mathrm{min})$ bioassay. Chemosphere 1997, 35, 2925-2938. [CrossRef]

35. Weber, E. Grundriß der Biologischen Statistik, 8. Aufl; Gustav Fischer Verlag: Stuttgart, Germany, 1980; pp. 534-543.

36. ISO 7027. Water Quality. Determination of Turbidity, Part 1: Quantitative Methods; International Organisation for Standardization: Geneva, Switzerland, 2016.

37. Strotmann, U.J.; Gendig, C.; Geldern, A.; Kuhn, A.; Klein, S. Optimization of a respirometric method for the determination of the heterotrophic yield of activated sludge bacteria. Chemosphere 1999, 38, 3555-3570. [CrossRef]

38. Peters, C.; Ahlf, W. Validation, Harmonization and Implementation of a Base-Set of Bioassays for the Assessment of Brackish and Marine Sediment Samples; Environmental Research of the Federal Ministry of the Environment, Nature, Conservation and Nuclear Safety: Berlin, Germany, 2003; Research Report 29925261 UBA FB 000508.

39. Fulladosa, E.; Murat, J.C.; Martínez, M.; Villaescusa, I. Patterns of metals and arsenic poisoning in Vibrio fischeri bacteria. Chemosphere 2005, 60, 43-48. [CrossRef] [PubMed]

40. Fulladosa, E.; Desjardin, V.; Murat, J.C.; Gourdon, R.; Villaescusa, I. Cr(VI) reduction into Cr(III) as a mechanism to explain the low sensitivity of Vibrio fischeri bioassay to detect chromium pollution. Chemosphere 2006, 65, 644-650. [CrossRef]

41. Fulladosa, E.; Murat, J.C.; Villaescusa, I. Effect of Cadmium (II), Chromium (VI), and Arsenic (V) on long-term viability and growth inhibition assays using Vibrio fischeri bacteria. Arch. Environ. Contamin. Toxicol. 2005, 49, 299-306. [CrossRef]

42. Ishaque, A.B.; Johnson, L.; Gerald, T.; Boucaud, D.; Okoh, J.; Tchounwou, P.B. Assessment of individual and combined toxicities of four non-essential metals ( $\mathrm{As}, \mathrm{Cd}, \mathrm{Hg}$ and $\mathrm{Pb}$ ) in the Microtox ${ }^{\mathrm{TM}}$ assay. Int. J. Environ. Res. Public Health 2006, 3, 118-120. [CrossRef] [PubMed] 
43. Broecker, B.; Zahn, R. The performance of activated sludge plants compared with the results of various bacterial toxicity tests-A study with 3.5-dichlorophenol. Water Res. 1977, 11, 165-172. [CrossRef]

44. Klecka, G.M.; Landi, L.P.; Bodner, K.M. Evaluation of the OECD activated sludge respiration inhibition test. Chemosphere 1985, 14, 1239-1251. [CrossRef]

45. Elnabrarawy, M.T.; Robideau, R.R.; Beach, S.A. Comparison of three rapid toxicity test procedures: Microtox ${ }^{\mathrm{TM}}$, Polytox $^{\mathrm{TM}}$ and activated sludge respiration inhibition. Toxicol. Assess. 1988, 3, 361-370. [CrossRef]

46. Gutierrez, M.; Extebarria, J.; de las Fuentes, L. Evaluation of wastewater toxicity: Comparative study between Microtox $^{\mathrm{TM}}$ and activated sludge oxygen uptake inhibition. Water Res. 2002, 36, 919-924. [CrossRef]

47. Yoshioka, Y.; Nagase, H.; Ose, Y.; Sato, T. Evaluation of the test method "activated sludge respiration inhibition test" proposed by the OECD. Ecotoxicol. Environ. Saf. 1986, 12, 206-212. [CrossRef]

48. Strotmann, U.J.; Weberruß, U.; Bias, W.R. Degradation of morpholine in several biodegradation tests and in wastewater treatment plants. Chemopshere 1993, 26, 1729-1742. [CrossRef]

Publisher's Note: MDPI stays neutral with regard to jurisdictional claims in published maps and institutional affiliations.

(C) 2020 by the authors. Licensee MDPI, Basel, Switzerland. This article is an open access article distributed under the terms and conditions of the Creative Commons Attribution (CC BY) license (http://creativecommons.org/licenses/by/4.0/). 